\title{
Ex-Ante Regulation and Ex-Post Liability under Uncertainty and Irreversibility: Governing the Coexistence of GM Crops
}

\author{
Volker Beckmann, Humboldt-Universität zu Berlin \\ Claudio Soregaroli, Università Cattolica, Cremona \\ Justus Wesseler, Wageningen University
}

\begin{abstract}
Ex-ante regulations and ex-post liabilities for using a new technology will induce additional costs for adopters. The standard model is advanced by including irreversibility and uncertainty and taking into account transaction costs of negotiating possible cost reductions. The case analysed is the coexistence policy for GM crops in the European Union. Results show, the design of the rules and regulations can provide strong incentives for regional agglomeration of GM and non-GM farmers.
\end{abstract}

JEL D81, L23, Q12, Q24, R3

Keywords Ex-ante regulation; ex-post liability; irreversibility; uncertainty; agglomeration

Correspondence Dr. Justus Wesseler, Environmental Economics and Natural Resources Group, Wageningen University, P.O.Box 8130, bode 129, 6700 EW Wageningen, The Netherlands, e-mail: justus.wesseler@wur.nl.

Volker Beckmann is an assistant professor, Division of Resource Economics, Institute of Agricultural Economics and Social Sciences, Faculty of Agriculture and Horticulture, Humboldt University, Berlin. Claudio Soregaroli is a researcher at the Università Cattolica, Piacenza. Justus Wesseler is an associate professor, Environmental Economics and Natural Resources Group, Social Science Department, Wageningen University, The Netherlands. The third author acknowledges funding from the EU TRANSCONTAINER project (Contract NO. Food 2006 023018) and from the EU ECOGEN project (Contract NO. QLK5-CT-2002-01666). 
conomics: The Open-Access, Open-Assessment E-Journal

\section{Introduction}

The future institutional environment for the coexistence of genetically modified crops (GM-crops) $)^{1}$, conventional crops and organic crops in Europe combines measures of ex-ante regulation and ex-post liability rules. Recognising Europe's heterogeneity in farm structures, crop patterns and legal environments, the European Commission decided to follow the principle of subsidiarity and states that "measures for coexistence should be developed and implemented by the Member States." (Commission of the European Communities 2003). Member States develop a variety of different coexistence rules and regulations (Beckmann, Soregaroli, and Wesseler 2006) that may have a profound impact on the adoption rate of GM-crops. The discussion on coexistence and the governance of the GMtechnology, however, is not limited to Europe. There is an ongoing debate in the United States, Canada, New Zealand and other countries (see e.g. Kershen 2002; Smyth, Khachatourians and Phillips 2002; Conner 2003; Falck Zepeda 2006).

Against this background we ask the following two questions: How does exante regulation and ex-post liability under irreversibility and uncertainty affect the adoption of GM crops? What are the implications for regional agglomeration of GM and non-GM crops?

Our contribution differs from previous studies on the subject that analyse the economics of public regulations of biotechnology during the research and development phase, such as Larason and Knudson (1991). We consider GMtechnologies that have been approved by the regulatory body, e.g. the European Food Safety Agency (EFSA), as being safe for human consumption and the environment, if grown according to pre-defined regulations. The present paper provides a comprehensive framework for the evaluation of coexistence at the farm level, in terms of adoption decision, regional agglomeration, minimum farm size, and the consequential effects of policy measures.

The literature on ex-ante safety regulations versus ex-post liability for harm discusses the welfare efficient conditions of using either one or both and assumes

1 There is some controversy about the use and meaning of the term genetically modified organism. We follow here the definition used by the FAO (Zaid et al. 2001), which defines a genetically modified organism as an organism "that has been transformed by the insertion of one or more transgenes." (p. 125), which applies to a single organism such as a seed corn or animal. 
the utility derived from harmful action is sufficiently large (e.g. Shavell 1987; Larson 1996; Schmitz, 2000; Boyer and Porrini 2004; Roe, 2004; Calcott and Hutton 2006). One of the results from that literature is favouring ex-ante regulations in case the injurer is subject to bankruptcy if being held liable.

We are more interested to discuss the situation where the utility is not sufficiently large and the harm causing firms are not subject to bankruptcy. In particular, we look at ex-ante regulations versus ex-post liabilities from the point of view of how this does effect technology adoption, firm growth and regional development. This is an aspect that so far has not been considered in the literature on ex-ante regulations versus ex-post liabilities. Further, while the standard literature only considers unilateral accidents where injurers can take precautionary actions or are forced to take precautionary actions, we allow for responses of the victims and bargaining possibilities between injurer and victim. One analysis that comes close to our case is Viscusi and Moore (1993). The authors analyse the case of product liability on research and development and innovation, where liability risks may result in bankruptcy or in extremely high insurance costs. While their study considers investment in innovations and considers liability issues only, we analyse the case of adoption of innovation and consider ex-ante regulations as well as ex-post liability. A combination of ex-ante regulations and ex-post liability rules and implications on adoption has been introduced by Soregaroli and Wesseler (2005) and Beckmann et al. (2006). We expand the model by explicitly considering transaction costs, which so far has been ignored by other authors investigating the relationship between coexistence policies and adoption of GM crops and discuss the implications for the comparative advantage of either being a GM or non-GM farmer. ${ }^{2}$ Our results show that ex-ante regulations and ex-post liability can induce regional agglomeration of the harm causing firms and can have important implications for regional growth as access to technical innovations can be hindered or supported by the regulators choice of ex-ante regulations and expost liability rules. While this has been mentioned by Beckmann and Wesseler (2007) the role of regulations on the irreversibility effect and in particular the relation ship between ex-post liability, transaction costs and the irreversibility effect has not been discussed in the relevant literature.

2 The GM farm has a comparative advantage in the production of GM crops as it can produce that good at a lower opportunity cost relative to the non-GM farm. 
The effect has been modelled by using a combined geometric Brownian motion and Poisson process (see Dixit and Pindyck 1994) applied to problems of ex-ante regulations and ex-post liability rules as in Soregaroli and Wesseler (2005) but extended by including transaction costs caused by regulatory policies. Results show these further increases the irreversibility effect and the costs of minimum distance requirements.

In more detail, coexistence is assessed under the existence of costs related to ex-ante regulations and ex-post liability, the presence of irreversible costs and uncertainty, and the consequential comparative advantages of different types of farms in becoming GM or non-GM producers. The impact of irreversibility and uncertainty on the comparative advantage of GM farms versus non-GM farms is the central theme of the paper. Irreversibilities and uncertainties are modelled using a combined geometric Brownian motion and Poisson process. While the applicability using a combination of the two processes for finding an analytical solution seem to be limited, we discuss how proper calibration of the parameters allows to use a combination of the two processes for a number of problems. Contrary to previous papers (Soregaroli and Wesseler 2005; Beckmann et al. 2006) we extend the model by considering transaction costs and illustrate how they affect the value of the technology. While previous studies addressing the coexistence issue have considered minimum distance requirements other regulations commonly found among the member states have largely been ignored. The framework we present can also find empirical application as illustrated in the example provided in section six of the work.

We proceed as follows. In section two we define what we mean by coexistence. In section three we introduce ex-ante regulations and ex-post liability under irreversibility and uncertainty into the model. Section four discusses the implications of ex-ante regulations and ex-post liabilities for technology adoption, and regional agglomeration of adopting farms. Section five discusses the implications for policy analysis and in particular the link between technology adoption and minimum farm size. Section six presents an illustrative example from Germany demonstrating the relevance of the issues considered by the theoretical model. In section seven we conclude. 
conomics: The Open-Access, Open-Assessment E-Journal

\section{$2 \quad$ A Definition of Coexistence}

The problem of coexistence is a classical "problem of social costs" as pointed out by Beckmann and Wesseler (2007). Farmers who plant GM crops may cause negative (or positive) external effects to non-GM or organic farmers through pollen drift or other forms of admixture. The admixture, in principle, can be two sided. GM crops may affect non-GM crops but non-GM crops may also affect GM crops. It is important to note here that the same physical effect, i.e. pollen flow, can have different economic impacts, depending on the institutional setting. The institutional and regulatory setting defines the rules of what is or is not to be called GM. In the case of GM crops, this largely depends on threshold levels and crop specificities and therefore it is not surprising that the definition of the threshold is subject to a strong political debate (Nischwitz et al. 2004). ${ }^{3}$

Drawing from Beckmann and Wesseler (2007), the coexistence value ( $v c$ ) of GM farming - $G$ - (non-GM farming - $N$-) of farm $i$, will be denoted by $v c_{G_{i}}^{\ell}$ $\left(v c_{N_{i}}^{\ell}\right)$ in case the GM farmer will be liable $(l)$ for any harm caused by planting GM crops and by $v c_{G_{i}}^{n}\left(v c_{N_{i}}^{n}\right)$ in case the GM farmer will not be held liable $(n)$. The interpretation of liability is that in the case where the GM farmer will be liable the property right is with the non-GM farmer, in the sense that the non-GM farmer has the right to produce non-GM crops and GM farmers have to take measure to protect that right and in the case where GM farmer are not liable they have the property right to plant GM crops and the non-GM farmer have to take appropriate measures.

Coexistence can than be defined by:

"A state described by a set of policies exogenous to the farmers that results in the planting of 'organic and/or non-organic-non-GM' and 'GM crops' at the same point in time in a pre-defined region with at least one farm i where $v c_{G_{i}}^{\ell}>v c_{N_{i}}^{\ell}$ and one where $v c_{G_{i}}^{\ell}<v c_{N_{i}}^{\ell}$ under a non-GM-farmer property right system and at least one farm where $v c_{G_{i}}^{n}>v c_{N_{i}}^{n}$ and one where $v c_{G_{i}}^{n}<v C_{N_{i}}^{n}$ under a GM-farmer property right system."

\footnotetext{
3 In the EU the current food-labelling threshold is $0.9 \%$ for GM-food (Commission of the European Communities 2005). It should be noted here that for organic farming no threshold has been decided yet. The commission proposes a $0.9 \%$ threshold level as well, which is heavily debated.
} 
For achieving the state of coexistence, regulators use a number of policies that can be classified in ex-ante regulations or ex-post liability rules. Those policies do affect the possibility of coexistence. However, it is not obvious to which extent coexistence policies will contribute to reaching the state of coexistence. In the following analysis we will assume that the property right is with the non-GM farmer, meaning to say $\mathrm{s}$ /he has the right to plant non-GM crops and farmers planting GM crops have to compensate and/or prevent damages to non-GM farmers. This system reflects the current situation in the EU.

\section{Ex-Ante Regulation and Ex-Post Liability}

\subsection{Coexistence Value under Ex-Ante Regulation and Ex-Post Liability Rules}

The starting point is the definition of the GM farmer's value function under exante regulation and ex-post liability rules. The value function of the GM farmer will be affected when complying with regulations; moreover, the possibility of facing ex-post liability for damages from cross pollination adds additional costs to those farmers that plant GM crops. The value of planting GM crops at farm $i$ can be defined as the value from GM cultivation $\left(v_{G_{i}}\right), p_{G_{i}} y_{G_{i}}-c_{G_{i}}$, with $p_{G_{i}}, y_{G_{i}}, c_{G_{i}}$ as the respective farm level price, quantity and cost vectors, minus the costs related to liability and its control, $\lambda_{i}$. The coexistence value of GM farming of farm $i$ under ex-ante regulation and ex-post liability is

$$
v c_{G_{i}}^{\ell}=v_{G_{i}}-\lambda_{i} .
$$

The expected costs related to liability are the sum of the costs of respecting ex-ante regulations, $r_{i}$, and the value of expected ex-post tort liability $t l_{i}$ :

$$
\lambda_{i}=E\left(r_{i}+t l_{i}\right) .
$$

The regulatory costs introduced in equation [2], $r_{i}$, are the sum of the fencing and compensation costs under certainty. Following Kolstad et al. (1990) and Ewerhart and Schmitz (1998) expected ex-post tort liability, $t l_{i}$, can be written as 


$$
t l_{i}=\mu_{i} \cdot d_{i} \cdot E\left(j_{i}\right)
$$

where, $\mu_{i}$ is the probability of causing an accident, in this case contamination of the neighbouring non-GM fields, $d_{i}$ is the monetary value of the damage, and $E\left(j_{i}\right)$ is the expected probability that the injurer will pay the damages. In our case, $E\left(j_{i}\right)$, can be interpreted as a function of the court's view and the probability of being sued by the neighbour who has suffered damage. From the previous equations the coexistence value function for the GM farmer, dropping the expectation operator to simplify notation, can be formulated as follows:

$$
v c_{G_{i}}^{\ell}=v_{G_{i}}-r_{i}(s, \text { reg })-\mu_{i}(s, \text { reg }) d_{i}(s, \text { reg }) j_{i}(\text { law })
$$

where $s$ is the size of GM crops planted, reg is the enforced GM legal standard for the region (e.g. country or federal state) and law is the tort liability system of the region.

Interpreting the variable reg as the minimum distance, $z$, one of the most common forms of ex-ante regulation, between the GM crop and the neighbouring non-GM crop we can write equation [1] as:

$$
v c_{G_{i}}^{\ell}=v_{G_{i}}-r_{i}(s, z)-\mu_{i}(s, z) d_{i}(s, z) j_{i}(\text { law })
$$

Assuming $v C_{N_{i}}$ is not affected by GM farming $\left(v C_{N_{i}}=v_{N_{i}}\right)$ a profit maximizing farmer $i$ would adopt a GM crop if the incremental benefit

$$
\Delta v C_{G_{i}}^{\ell} \equiv v C_{G_{i}}^{\ell}-v_{N_{i}}>0 \text {. }
$$

\subsection{Introducing Irreversibility and Uncertainty}

So far it was assumed that incremental benefits are certain and the farmer did not face reduced costs while deciding to adopt the GM technology. However, it could be the case that some of the costs are irreversible: for example, the GM crop requires specific machinery or the GM cultivation could make it difficult for the farmer to switch back to the non-GM status. These difficulties could include additional practices for the control of volunteers or a required minimum number of years of non-GM cultivation for a field to be considered for producing non-GM 
products. While irreversibility aspects are not considered by policy makers as the ban on GM maize in France, Germany and Italy illustrates, they seem to be relevant for farmers. In Germany and Italy famers have sued the government for not having the right to plant GM maize. One of the major arguments for the German farmers was the expenses they had for the GM seeds they now were not allowed to be use. They further claimed irreversible environmental benefits of using $\mathrm{Bt}$ maize as well as the higher fodder value of BT maize by reducing mycotoxins. On the other hand, farmers have expressed reluctance of adopting GM oilseed rape, if they face regulations requiring a longer waiting period before they can grow non-GM oilseed rape as well as if neighbours have a negative attitude towards GM crops (Breustedt et al. 2008), both indicating irreversible adoption costs are part of the adoption decision. The multi-period time frame also adds uncertainty to the farmers' adoption decision as future yields, prices and costs are not generally known with certainty.

In the presence of net-irreversible costs, uncertainty and flexibility, the value of a GM crop is not simply the difference between the present value of future benefits and costs but the sum of this difference plus the value of the option to plant GM crops (Wesseler 2003). More formally, when some costs are irreversible, costs and benefits are uncertain and the decision to adopt can be postponed, a profit maximizing farmer maximizes the option value of the adoption possibility. Hence, we can write for the adoption decision under irreversibility and uncertainty excluding ex-ante regulation and ex-post liability rules, with $\sim$ indicating the value of co-existing under irreversibility and uncertainty:

$$
F\left(\widetilde{\Delta C_{G_{i}}}\right)=\max E\left[\left(\Delta v C_{G_{i}}\left(v_{G_{i}}, v_{N_{i}}\right)-I R_{i}\right) e^{-\rho_{i} T}\right]
$$

or including ex-ante regulation and ex-post liability rules:

$$
F\left(\Delta \widetilde{v c_{G_{i}}^{\ell}}\right)=\max E\left[\left(\Delta v c_{G_{i}}^{\ell}\left(v_{G_{i}}, v_{N_{i}}, r_{i}, t l_{i}\right)-I R_{i}^{\ell}\right) e^{-\rho_{i} T}\right]
$$

with $I R_{i}$ the net-irreversible costs excluding irreversible regulatory costs and $I R_{i}^{\ell}$ the net-irreversible costs including irreversible regulatory costs.

There is some potential controversy about what we mean by net irreversible costs. $I R_{i}$ indicates the net-irreversible costs, the difference between irreversible costs $I_{i}$ and irreversible benefits $R_{i}$, of farmers who adopt GM-crops. Both, $I_{i}$ and 
$R_{i}$, are those at the private level and include sunk costs such as new machinery for higher density planting of herbicide tolerant soy beans or positive health benefits due to a change in pesticide use (Weaver and Wesseler 2004). $I R_{i}^{\ell}$ indicates the net-irreversible costs under regulation and liability rules. $I R_{i}^{\ell}$ includes in addition to $I R_{i}$ irreversible transaction cost, $I R_{i}^{\text {tc }}$, that may arise due to negotiations with neighbouring farmers. Some of the transaction costs are assumed to be irreversible, as if farmers move out of planting GM crops, time and money spent on arrangements with neighbours to comply with and reduce regulatory and liability costs are worthless.

$$
I R_{i}^{\ell}=I R_{i}+I R_{i}^{t c}
$$

with

$$
\begin{aligned}
& I R_{i}=I_{i}-R_{i}>0, \forall i=1, \ldots, k \\
& I R_{i}^{t c}=I_{i}^{t c}-R_{i}^{t c}>0, \forall i=1, \ldots, k
\end{aligned}
$$

The uncertainty that in combination with the net irreversible cost creates the option value for adopting GM crops is represented by the following stochastic process:

$$
d\left(\Delta v c_{G_{i}}^{\ell}\right)=\alpha\left(\Delta v c_{G_{i}}^{\ell}\right) d t+\sigma\left(\Delta v c_{G_{i}}^{\ell}\right) d z+\left(\Delta v c_{G_{i}}^{\ell}\right) d q_{i}
$$

where $\Delta v c_{G_{i}}^{\ell}=v_{G_{i}}-v_{N_{i}}-r_{i}$ evolves under a combined geometric Brownian motion and Poisson process. $\alpha$ is the drift of the Brownian motion, $d z$ is the increment of a Wiener process, $d t$ is the marginal increment in time and $d q_{i}$ is the increment of a Poisson process. The first two terms on the right-hand-side of equation [9] are common for modelling incremental benefits of GM crops under irreversibility and uncertainty (e.g. Wesseler et al. 2007; Demont et al. 2004; Morel et al. 2003; Wesseler 2003). The drift rate $\alpha$ captures the exponential growth of the difference in revenues between GM and non-GM crops, the expected trend, and the variance rate $\sigma$ deviations from the trend. The third term represents tort liability modelled as the risk of a jump in the profit when the farmer is held liable. More precisely, 


$$
\begin{aligned}
& d z=\varepsilon_{t} \sqrt{d t}, \text { and } \\
& d q_{i}=\left\{\begin{array}{cc}
0 & \text { with probability } 1-\gamma_{i} \mathrm{dt} \\
-\phi_{i} & \text { with probability } \gamma_{i} \mathrm{dt}
\end{array}\right.
\end{aligned}
$$

where $\varepsilon_{t}$ is normally distributed with zero mean and unit standard deviation, $\gamma_{i}$ is the mean arrival rate of a Poisson process, and $\phi_{i}$ the percentage of the ex-post liability costs of $\Delta v c_{G_{i}}^{\ell}$.

From the above equation and the opportune boundary conditions the standard rule for the adoption decision under irreversibility and uncertainty, assuming $\phi=$ 1, can be derived (Dixit and Pindyck 1994): ${ }^{4}$

$$
\Delta v c_{G_{i}}^{\ell}>\left[\Delta v c_{G_{i}}^{\ell}\right]^{*}=\left(\frac{\beta_{1_{i}}}{\beta_{1_{i}}-1}\right)\left(\rho_{i}-\alpha_{i}+\gamma_{i}\right) I R_{i}^{\ell}
$$

Equation [11] says adopt GM crops if the current incremental coexistence value of GM farming, $v_{G_{i}}-v_{N_{i}}$ minus the regulatory costs $r_{i}$, is greater than the hurdle value $\left[\Delta v c_{G_{i}}^{\ell}\right]^{*}$. This hurdle value depends among others on the regulatory and liability costs as they have an impact on the irreversible transaction costs and due to tort liability an impact on $\gamma_{i}$.

Please note, we get a farm specific hurdle rate, even if the drift and variance rate of the geometric Brownian motion are homogenous over all farms as the mean arrival rate of the Poisson process is farm specific and depends on the landscape and number and distance of non-GM farms in the neighbourhood.

With the now specified decision rule of adopting GM crops considering exante regulatory and ex-post liability costs under irreversibility and uncertainty, we can have a closer look at the coexistence issue and regional agglomeration.

\footnotetext{
${ }^{4} \phi_{i}$ is assumed to be one to derive an analytical solution. Using a different value for $\phi_{i}$ requires finding a solution numerically.
} 
conomics: The Open-Access, Open-Assessment E-Journal

\section{$4 \quad$ Adoption and Spatial Agglomeration Effects under Irreversibility and Uncertainty}

\subsection{Adoption Effects}

To see the effects of ex-ante regulation and ex-post liability rules on adoption and regional agglomeration we start by looking at the initial situation without any irreversibility and uncertainty as well as liability system. This situation is depicted in Figure 1. The horizontal axis illustrates the benefits for farmers staying non-GM and the vertical axis the benefits for becoming a GM-farmer. Point A1 indicates a situation where the incremental benefits from planting non-GM crops for farmer a are positive $\left(v_{N_{a}}>v_{G_{a}}\right)$, whereas at point $B^{1}$ the incremental benefits from GM crops for farmer $b$ are positive $\left(v_{G_{b}}>v_{N_{b}}\right)$. Under the assumption that $v_{G_{b}}>v_{N_{b}}$ and $v_{N_{a}}>v_{G_{a}}$ the comparative advantage of the two farm is defined by

$$
C^{1}=\left(v_{G_{b}}-v_{N_{b}}\right)-\left(v_{N_{a}}-v_{G_{a}}\right)
$$

This is represented by point $C^{1}$ in Figure 1 . As the incremental benefits of farmer $b$ are larger than the incremental benefits of farmer $a$ point $C^{1}$ is above the $45^{\circ}$ degree line indicating a comparative advantage for farmer $b$.

The situation changes with the introduction of irreversibility and uncertainty. The term $\kappa_{i}=\left(\frac{\beta_{1_{i}}}{\beta_{1_{i}}-1}\right)\left(\rho_{i}-\alpha_{i}\right) I R_{i}$, representing the value of waiting, has an additive effect on the comparative advantage of the two farms: assuming

$$
\begin{aligned}
v C_{G_{b}}>v C_{N_{b}} & ; v C_{N_{a}}>v C_{G_{a}}, \\
C^{2} & =\left(v C_{G_{b}}-v C_{N_{b}}\right)-\left(v C_{N_{a}}-v C_{G_{a}}\right) \\
& =\left(\left(v_{G_{b}}-\kappa_{b}\right)-v_{N_{b}}\right)-\left(v_{N_{a}}-\left(v_{G_{a}}-\kappa_{a}\right)\right) .
\end{aligned}
$$




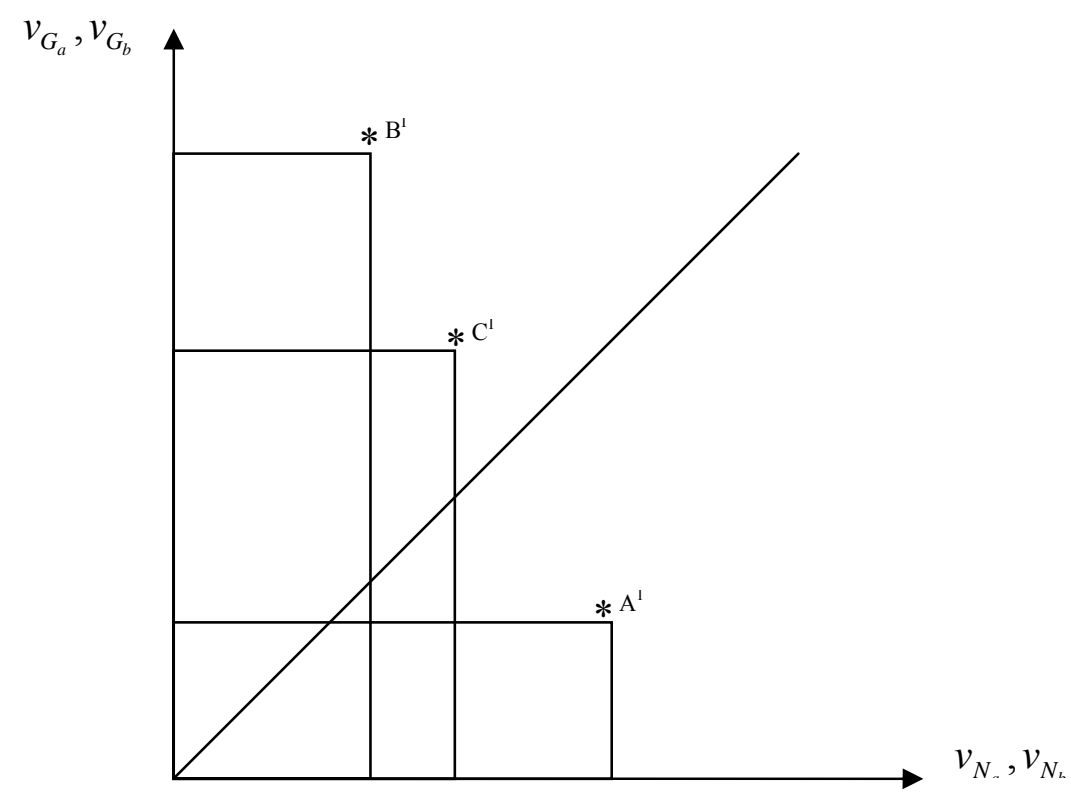

Figure 1. Distribution of adopter and non-adopters without net-irreversible costs and exante regulation and ex-post liability.

As depicted in Figure 2, irreversibility and uncertainty at the production level have the following implications. Firstly, incremental benefits from GM-crops are reduced due to the irreversibility and uncertainty effect $\left(\kappa_{i}\right)$. This is illustrated by a vertical downward movement of farmer $b$ from point $B^{1}$ to point $B^{2}$. If farmer $a$ is not affected the new comparative advantage is at point $C_{w / o}^{2}$ which is still above the $45^{\circ}$-degree line. But it is also reasonable to assume that farmer $a$ would face irreversibility and uncertainty as well if s/he would consider adopting GM crops (see equation [12b]). Hence, under irreversibility and uncertainty the benefits of farmer $a$ for staying non-GM do increase. This is indicated by a horizontal move from point $\mathrm{A}^{1}$ to point $\mathrm{A}^{2}$. The new comparative advantage is indicated by point $C_{w}^{2}$. This point is located below the $45^{\circ}$-degree line. Now, the comparative advantage has moved from GM farmer $b$ to the non-GM farmer $a$. This effect is 


$$
v_{G_{a}}, v_{G_{b}}-\frac{\beta_{1_{b}}}{\beta_{1_{b}}-1}\left(\rho_{b}-\alpha_{b}\right) I R_{b}
$$

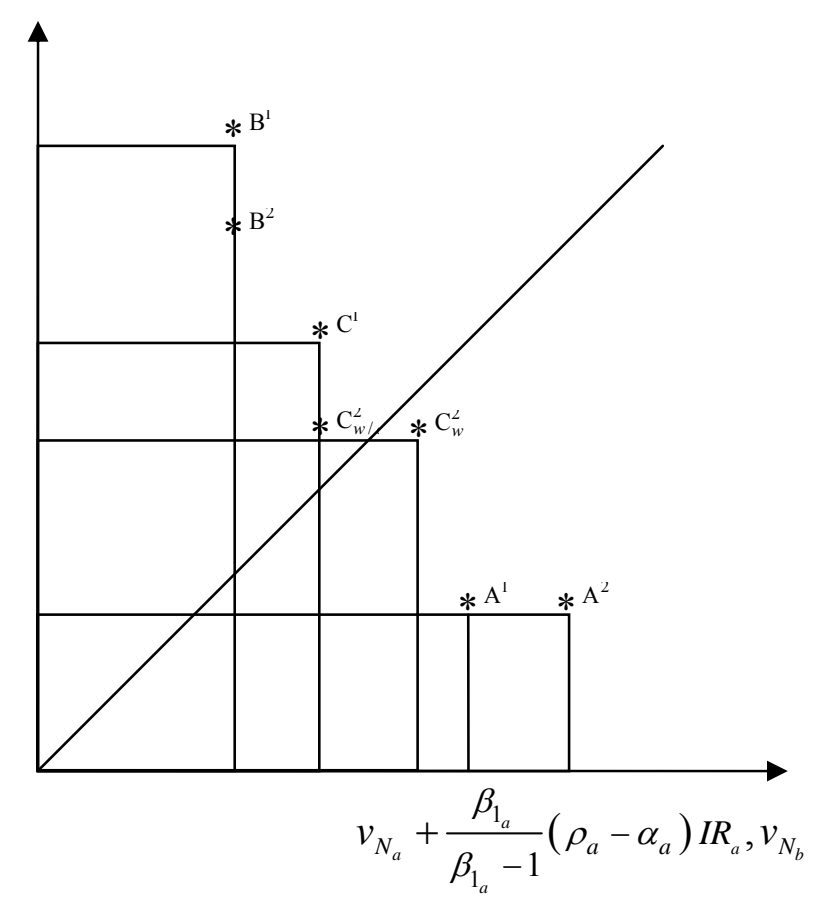

Figure 2. Distribution of adopter and non-adopters with net-irreversible production costs and without ex-ante regulation and ex-post liability.

independent of ex-ante regulatory and ex-post liability costs and has already been studied for the adoption of GM crops (e.g. Demont et al. 2004; Morrel et al. 2003; Scatasta et al. 2006).

Now, if the GM farmer is liable for possible damages, the costs for complying with the regulations have influences on the $\kappa_{i}$ term, including the hurdle rate and irreversible costs, that becomes $\kappa_{i}^{\ell}=\left(\frac{\beta_{1_{i}}}{\beta_{1_{i}}-1}\right)\left(\rho_{i}-\alpha_{i}+\gamma_{i}\right) I R_{i}^{\ell}$; also, liability 
has an additive effect on the comparative advantage of the two farms: under the same assumptions of equation [12b],

$$
\begin{aligned}
C^{3} & =\left(v C_{G_{b}}-v C_{N_{b}}\right)-\left(v C_{N_{a}}-v C_{G_{a}}\right) \\
& =\left(\left(v_{G_{b}}-\kappa_{b}^{\ell}-r_{b}\right)-v_{N_{b}}\right)-\left(v_{N_{a}}-\left(v_{G_{a}}-\kappa_{a}^{\ell}-r_{a}\right)\right) .
\end{aligned}
$$

The new situation is depicted in Figure 3. Again, we can observe two main effects. First, ex-ante regulatory and ex-post liability costs increase the hurdle value of adoption. This is indicated by a downward vertical move from point $\mathrm{B}^{2}$ to point $\mathrm{B}^{3}$. Please note, planting GM crops is still profitable for farmer $b$. Second, the value of staying non-GM either remains the same or further increases. The benefits costs for staying non-GM will remain the same for farmer $a$, if $\mathrm{s} / \mathrm{he}$ is surrounded by GM-farms only and coexistence policies require to keep a distance to, inform and compensate non-GM farmers for harm. In that case, if $s /$ he also becomes a GM-farmer there are no additional regulatory and liability costs as there is no non-GM farm left. Farmer $a$ remains at point $A^{2}$. The comparative advantage for staying non-GM in this case is indicated by point $C_{w / o}^{3}$. In case there are other non-GM farmers in the neighbourhood switching to GM crops adds additional compliance costs for farmer $a$. Hence, the benefits of staying non-GM further increase as indicated by point $A^{3}$. The comparative advantage for the non-GM farmer further increases as indicated by the move to the right from point $C_{w / o}^{3}$ to point $C_{w}^{3}$.

It is important to recognize, that liability increases the irreversible costs due to additional negotiation costs. Every unit of irreversible costs demands more than one unit of incremental benefits. Regulation and liability rules have two effects on potential adopters. First, regulations directly decrease the incremental benefits (see equation 7). The adoption rate would decrease even without ex-post liability. Second, ex-post liability increases $\kappa_{i}^{\ell}$. In the appendix we show $\partial\left(\frac{\beta_{1_{i}}}{\beta_{1_{i}}-1}\left(\rho_{i}-\alpha_{i}+\gamma_{i}\right)\right) / \partial \gamma_{i}>0$. This effect further increases the required incremental benefits for adoption. The coexistence policy implications will be discussed in more detail in section five. 


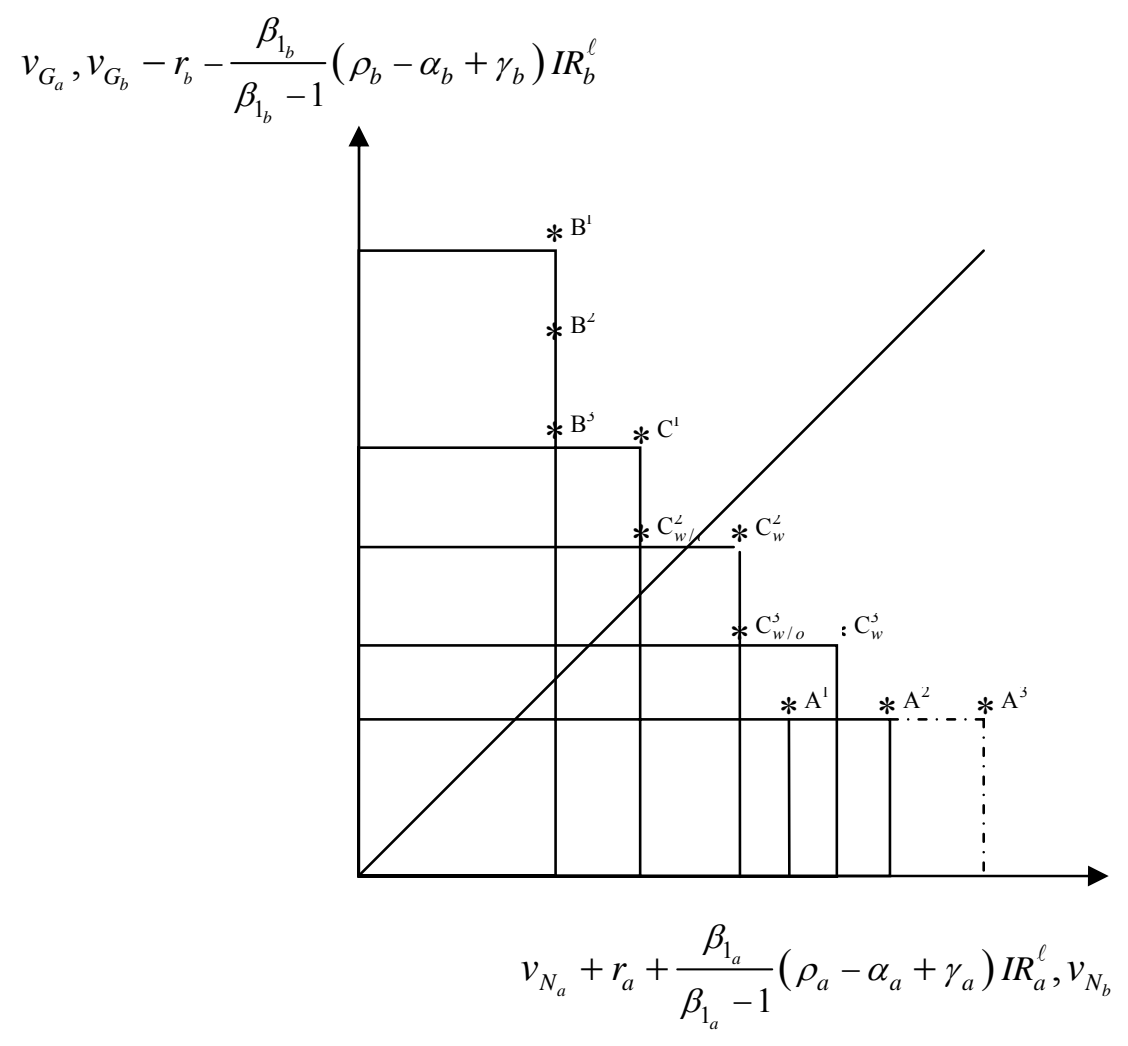

Figure 3. Distribution of adopter and non-adopters with net-irreversible production costs under ex-ante regulation and ex-post liability.

Figure 3 clearly shows that ex-ante regulatory and ex-post liability costs for GM-farmers reduce the adoption of the technology and favours non-GM farming. The opposite can be shown to hold for providing the GM farmer with the property right of planting GM-crops. The effect can be explained by using Figure 2. If the fencing costs of the non-GM farmer are equivalent to the irreversibility effect at production level then farmer $a$ would move back from point $\mathrm{A}^{2}$ to point $\mathrm{A}^{1}$. The comparative advantage in the case of the production right is with the GM-farmer and the point illustrating the situation is point $C_{w / o}^{2}$. 


\subsection{Agglomeration Effects}

The rules and regulations governing coexistence not only affect adoption directly, they also set incentives for the GM and non-GM farmer to collaborate with neighbours. Consider Figure 4 which is a comparison between the benefits and costs before and after the introduction of regulation and liability.

The horizontal axis represents non-GM farms with $v_{N_{a}}-v_{G_{a}}>0$ and the vertical axis GM farms with $v_{G_{b}}-v_{N_{b}}>0$. Any point in the quadrant indicates the situation between a non-GM and GM farm. All points above (below) the $45^{\circ}$ degree line indicate situation where the incremental benefits of the GM (non-GM) farmer are larger than the incremental benefits for the non-GM (GM) farmer.

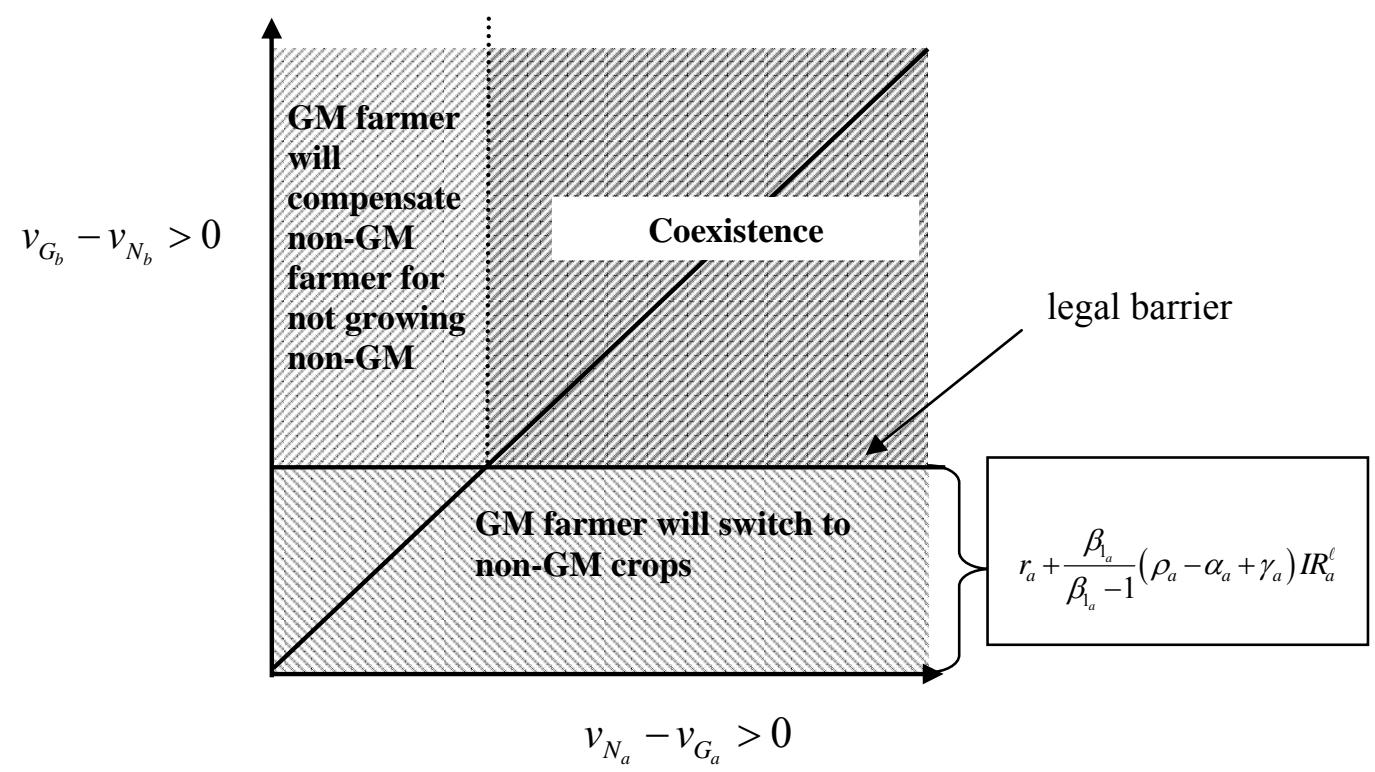

Figure 4: Agglomeration effects induced by ex-ante regulation and ex-post liability

Three situations to adapt to ex ante regulations and ex post liability rules do exist. If the incremental benefits $v_{G_{b}}-v_{N_{b}}$ for GM farmers are less than the costs to comply with the rules and regulation, they are below the legal barrier, they will not adopt the GM crop and become (or stay) non-GM farmers. This will be a likely situation for areas where the benefits from the technology are small and hence, 
potential adopters will stay non-GM. In those regions there will be no coexistence between GM and non-GM farmers. This is in Figure 4 the shaded area below the legal barrier. An excellent example is the voluntary GMO free zone in the Uckermark of Germany (Nischwitz et al. 2005).

In those areas where the incremental benefits for GM farmers are above the legal barrier and the incremental benefits for the farmer staying non-GM are smaller than the incremental benefits for the GM farmer, GM farmers can compensate the non-GM farmers and convince them to become GM farmers as well. This is the left shaded area above the legal barrier in Figure 4. In those regions an agglomeration of GM farmers will happen and again there will be no coexistence between GM and non-GM farmers.

The third situation resembles regions where GM as well as non-GM farmers show high incremental benefits. In those regions the incentives for the GM farmer is to grow the crops, comply with the regulations and in case of liability pay for the possible damage. The GM farmer has no economic incentive to compensate the neighbouring non-GM farmer to become a GM farmer. There is also no economic incentive in that situation to become a non-GM farmer. In this situation coexistence between GM and non-GM farmers will emerge.

\section{$5 \quad$ Implications for Policy Analysis}

The model presented in the previous sections allows to deal with the problem of coexistence in the context of policy assessment. Several policy tools and regulations can impact, directly or indirectly, on the variables of the model, therefore having an effect on GM-adoption and agglomeration of farms. Moreover, the model allows for heterogeneity of farms and it can possibly be extended to take into account for alternative distributions of farms' characteristics.

The variables that can be influenced by the policy and institutional environment are the costs of respecting ex-ante regulations $\left(r_{i}\right)$, the mean arrival rate of a Poisson process $\left(\gamma_{i}\right)$, the percentage $\left(\phi_{i}\right)$ of the ex-post liability costs of $\Delta v C_{G_{i}}^{\ell}$, the net-irreversible costs under regulation and liability rules $\left(I R_{i}^{\ell}\right)$, and directly the value of GM $\left(v_{G_{i}}\right)$ and non-GM cultivation $\left(v_{N_{i}}\right)$. 
While the liability system applies ex-post, after harm has been done, ex-ante regulations are favoured by many EU member-states. The next paragraph illustrates the link between the parameters of the model and one particular form ex-ante regulation that deserves special attention: the minimum distance requirement between GM and non-GM farms.

\subsection{Minimum Distance Requirements, Farm Size and Adoption}

Minimum distance requirements are common instrument of coexistence policies among EU member states (Beckmann, Soregaroli, Wesseler 2006). Soregaroli and Wesseler (2005) show that assuming reasonable functional forms minimum distance requirements have two effects. On the one hand they increase the regulatory costs on the other hand they decrease the expected future liability costs. But minimum distance requirements do also induce a threshold affect. The minimum distance requirements do determine the minimum farm size needed for adoption. They also define for larger farms a minimum of area that needs to be seta-side for non-GM crops.

From equation [11], the relationship between minimum adoption size $\mathrm{s}$ and minimum distance requirements $z$, with $z^{o}$ indicating the area for distance requirement, the threshold effect, can be found from the following

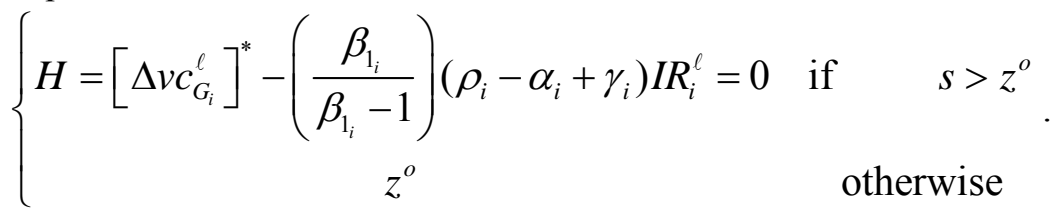

As long as the minimum farm size is not greater than $z^{o}$ adoption will not be possible. This result is trivial but has already important implications for adoption. Ex-ante minimum distance requirements discriminate against smaller farms, farms with a size less than $z^{o}$. This is not the only effect through which ex-ante minimum distance requirements discriminate against smaller farms.

From the implicit function theorem it is possible to write for the case $s>z^{o}$ :

$$
\partial \underline{s} / \partial z=-\frac{\partial H / \partial z}{\partial H / \partial s}
$$

and applying this to $H$ provides 
conomics: The Open-Access, Open-Assessment E-Journal

$$
\begin{aligned}
& \partial \underline{s} / \partial z=-\frac{\partial\left[\Delta v c_{G_{i}}^{\ell}\right]^{*} / \partial z-\left[\frac{\partial\left(\frac{\beta_{1_{i}}}{\beta_{1_{i}}-1}\right)}{\partial z}\left(\rho_{i}-\alpha_{i}+\gamma_{i}\right)+\left(\frac{\beta_{1_{i}}}{\beta_{1_{i}}-1}\right) \frac{\partial\left(\rho-\alpha_{i}+\gamma_{i}\right)}{\partial z}\right] I R_{i}^{\ell}}{\frac{\partial\left[\Delta v c_{G_{i}}^{\ell}\right]^{*}}{\partial s}-\left(\frac{\beta_{1_{i}}}{\beta_{1_{i}}-1}\right)\left(\rho_{i}-\alpha_{i}+\gamma_{i}\right) \frac{\partial I R_{i}^{\ell}}{\partial s}} \\
& -\frac{\left(\frac{\beta_{1_{i}}}{\beta_{1_{i}}-1}\right)\left(\rho_{i}-\alpha_{i}+\gamma_{i}\right) \frac{\partial I R_{i}^{\ell}}{\partial z}}{\frac{\partial\left[\Delta v c_{G_{i}}^{\ell}\right]^{*}}{\partial s}-\left(\frac{\beta_{1_{i}}}{\beta_{1_{i}}-1}\right)\left(\rho_{i}-\alpha_{i}+\gamma_{i}\right) \frac{\partial I R_{i}^{\ell}}{\partial s}}
\end{aligned}
$$

Given that at the break-even point of minimum size $\underline{s}$ an increase in the farm size implies a higher increase in the extra profits than in the extra ex-ante regulations and ex-post liability costs, the denominator of equation [13] can be considered to be positive around $s$ and we can write:

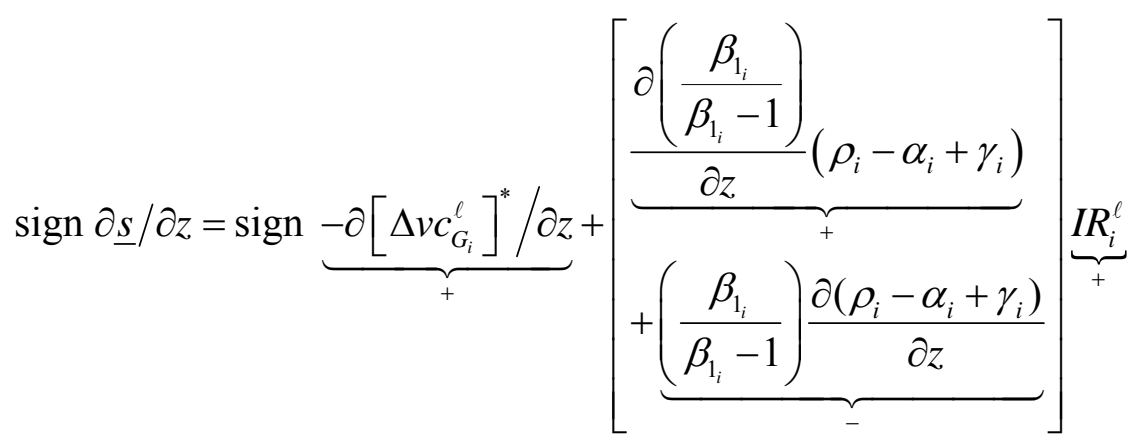

$$
\begin{aligned}
& +\underbrace{\left(\frac{\beta_{1_{i}}}{\beta_{1_{i}}-1}\right)\left(\rho_{i}-\alpha_{i}+\gamma_{i}\right) \frac{\partial I R_{i}^{\ell}}{\partial z}}_{+}
\end{aligned}
$$

Even if the sign for equation [14] is ambiguous, ex-ante minimum distance requirements do have a minimum farm size effect as can be seen by the last term. The two terms in the square brackets indicate the effect of an increase in minimum 
distance requirements on ex-post liability cost. The first term is positive which can be explained by the positive effect of an increase in minimum distance requirements on future liability. The future value of the project increases and the value of waiting to adopt the technology does increase. The second term is negative and shows the effect of an increase in minimum distance requirements on the immediate benefits of adopting GMOs through a decrease in the actual discount rate $1 /\left(\rho_{i}-\alpha_{i}+\gamma_{i}\right)$. Which effect dominates is not obvious (Soregaroli and Wesseler, 2005). For reasonable parameter values the overall effect of the two terms in square brackets is positive, the sign of equation [13] will be positive as well. Even if the sign of the square brackets is negative, irreversible cost do increase the minimum farm size for adoption. Only if $\partial I R_{i}^{\ell} / \partial z=0$ there might be no minimum farm size effect because of irreversible costs.

\subsection{Ex-post Liability Rules and Adoption}

$\gamma_{i}$ and $\phi_{i}$ influence directly the value of expected ex-post tort liability. $\gamma_{i}$ is a function of the legislation and the court view, so it is directly linked with the legal enforcement of the law in the territory, but also to the farmer' characteristics and ex-ante actions to avoid liability (fencing and compensation costs). In the model presented, $\gamma_{i}$ has a single value, but the modelling can be extended to consider a discrete or continuous distribution of the parameter to also accommodate for different values of $\phi_{i}$. Variations in $\gamma_{i}$ can have a substantial influence on the comparative advantage of farms and on the results of regional agglomeration. In the appendix we show that an increase in $\gamma_{i}$ increases $\kappa_{i}^{\ell}$ and, hence reduces immediate adoption. In case of a legal system using joint and several liability in combination with strict liability as in the case for Germany the expected value of $E\left(j_{i}\right)$ will be much higher as in the case of strict liability for GM farmers only, such as in Poland or Ireland. The expected value of ex-post liability costs in this case will be higher as under a fault-based liability system such as in Denmark. The expected value of being sued, $E\left(j_{i}\right)$, can be expected to be even lower in countries where liability is based on the civil law such as in the Czech Republic. The differences in the ex-post liability costs can be explained by the differences in $E\left(j_{i}\right)$. The differences in $E\left(j_{i}\right)$ can be explained by the easiness of suing the GM farmer. 
conomics: The Open-Access, Open-Assessment E-Journal

\section{An Illustrative Example: Brandenburg, Germany}

The state of Brandenburg is located in the eastern part of Germany. As in all of East Germany, Brandenburg is characterised by large scale farming. In 2005, 6,669 farms cultivated 1.415 Million hectare of utilised agricultural area (UAA), of which $74 \%$ was arable land (Statistische Berichte 2006a). The average farm size was 200 hectare UAA, with $69 \%$ of the UAA cultivated in farms larger than 500 hectare. In 2005 the total cultivation of maize was 116,500 hectare, the majority of 94,000 hectare being green maize and 22,500 ha grain maize (Table 1). The share of maize in the arable land amounted to $11.1 \%$ (Statistische Berichte 2006b).

Brandenburg shows a comparatively high share of organic agriculture. In $2005,9.8 \%$ of the UAA was cultivated as organic (Statistische Berichte 2006c). This share varies significantly from region to region. While the NUTS $3^{5}$ region Dahme-Spreewald showed the highest share of organic agriculture with $29.3 \%$, Elbe-Elster had the lowest with $2.1 \%$. Compared to conventional farming, maize is less important in organic agriculture and only green maize is grown which amounts to 2,300 hectare in $2005(1,97 \%$ of the total maize area grown in Brandenburg). The share of organic maize in the organic arable land amounts only to $2.58 \%$.

The European Corn Borer (ECB) is considered an important maize pest in Brandenburg. The problem is of great spatial heterogeneity. The eastern parts of Brandenburg are the mostly affected, in particular the area known as the Oderbruch (part of the NUTS 3 region Märkisch-Oderland). In the eastern parts of Brandenburg, the infestation frequency is estimated with $50 \%$ and above. In other parts of Brandenburg the infestation level is about 20\% (Landtag Brandenburg 2005). Some studies estimate the total maize area infected annually by the ECB in Brandenburg with 20,000 hectares, which is $17 \%$ of the total maize area cultivated in 2005 (Degenhart et al. 2003).

5 NUTS refers to the Nomenclature of Territorial Units for Statistics a geocode standard developed by the EU for diving the EU in administrative divisions. 
conomics: The Open-Access, Open-Assessment E-Journal

Table 1. Maize Cultivation in Brandenburg, 2005

\begin{tabular}{lll}
\hline & Hectares & Percent \\
\hline Total cultivated maize & 116,500 & 100 \\
Green maize & 94,000 & 80.69 \\
Grain maize & 22,500 & 19.31 \\
Organic green maize & 2,300 & 1.97 \\
Vulnerable to corn borer* & 20,000 & 17.17 \\
Bt-maize 2005** & 129 & 0.11 \\
\hline
\end{tabular}

Source: Statistische Berichte $(2006 \mathrm{~b}, \mathrm{c}),{ }^{*}$ Degenhardt et al $(2003),{ }^{* *}$ Standortregister (2006)

The German regulations for coexistence include mandatory registration of areas to be planted with GM crops 3-9 months before planting, following good agricultural practices for planting GM crops which includes a distance to neighbouring maize fields of 20 meters. Strict and joint and several liability applies in case the non-GM maize can not be marketed anymore due to adventitious presence of Bt-maize grain (Commission of the European Communities 2006)

Since the Gentechnikgesetz (Bundesrat 2005), the German law regulating the planting of GM crops, has come into force in January 2005, Brandenburg has been the leading state in the cultivation of GM-crops and Bt-maize in particular. In 2005, 341 ha of GM-crops have been planted in Germany, 129 hectares of them (i.e. 38\%) in Brandenburg (Table 2). This share increased in 2006. From 951 hectares GM-crops planted in Germany in 2006447 (47\%) hectares are planted in Brandenburg. The by far most important variety is Bt-maize MON-00810-6, which amounts to up to $99.5 \%$ of all GM-crops grown in Brandenburg. Some farms withdraw the registered area partly or totally (Table 3). In 2006, 11 notifications 
conomics: The Open-Access, Open-Assessment E-Journal

Table 2. Cultivation of GM-crops in Brandenburg and Germany, 2005-2006

\begin{tabular}{lcccc}
\hline & \multicolumn{2}{c}{2005} & \multicolumn{2}{c}{2006} \\
& Hectares & $\%$ & Hectares & $\%$ \\
\hline Germany & 341.59 & 100 & 951.32 & 100 \\
Brandenburg & 129.42 & 37.9 & 447.48 & 47.0 \\
\hline
\end{tabular}

Source: Standortregister, 26.06.2006

Table 3. Cultivation of Bt-Maize MON-00810-6 in Brandenburg

\begin{tabular}{lcc}
\hline & 2005 & 2006 \\
\hline Notifications to grow Bt-maize, number & 8 & 37 \\
Partly withdrawn notifications, number & 4 & 11 \\
$\begin{array}{l}\text { Totally withdrawn notifications, number } \\
\begin{array}{l}\text { Totally withdrawn notified Bt-maize area, } \\
\text { hectare }\end{array}\end{array}$ & n.a. & 6 \\
$\begin{array}{l}\text { Cultivated Bt-maize area, hectares } \\
\begin{array}{l}\text { Average cultivated Bt-maize field size, } \\
\text { hectares }\end{array}\end{array}$ & 128.69 & 180.52 \\
\hline
\end{tabular}

Source: Standortregister, 26.06.2006

were withdrawn with a notified area of about 180 hectare which is about one third of the totally announced area. Unfortunately, data on the area that was partly withdrawn does not exist in the GM-crop register.

Märka, a regional grain trader, announced in 2005 to buy Bt-maize as well as non Bt-maize grown within a distance of 100 meters to Bt-maize areas at market price. The objectives were to signal to GM farmers that there is a market for their product as well as to non-GM farmer that they can sell their grain maize without a 
down payment in case of adventitious presence of GM grain maize in the supposed to be non-GM grain maize. In combination with the relatively high ECB pressure and the large average farm size economic incentives for adopting Bt-maize are high. Degenhardt et al. calculate incremental benefits of $93 €$ per hectare for Btmaize in the Oderbruch region of Brandenburg. This amounts to an annual average incremental benefit of about $1340 €$ per Bt-maize growing farm. Despite this, only about $2.2 \%$ of the UAA for grain maize in Brandenburg has been planted with Btmaize in 2006.

The model presented can explain the low adoption rate due to ex-ante regulatory and ex-post liability costs and the irreversibility effect. In the case presented the ex-ante regulatory costs can be considered to be low, as Märka's policy actually controls for the distance requirements. Also, the actual ex-post liability costs are close to zero due to the promise by Märka to buy the harvest from neighbouring fields. Nevertheless, expected ex-post liability costs are high. Nischwitz et al. (2004) report results of a case study where the major reason of farmers who are voluntary members of a GM free zone 6 (30\% of the respondents) to become GM farmers, would be the removal of the risk of being held liable. In addition irreversible costs do exist in the form of getting acquainted with the German rules and regulations to be followed for planting Bt-maize.

\section{$7 \quad$ Conclusions}

The difference in incremental benefits and costs between GM and non-GM farmers provide incentives for regional agglomeration of either GM or non-GM farms. We show that the incremental benefits for becoming a GM farmer need to increase due to the irreversibility effect of the ex-ante regulations and ex-post liability rules compared to a situation without ex-ante regulations and ex-post liability rules. Minimum distance requirements between non-GM and GM farms increases the minimum farm size necessary for adopting the technology and therefore has a farm size effect as already pointed out by Beckmann (2005). The

6 Until December 2006, five GM-free zones have been established in Brandenburg associating 204 farmers and approximately 80.140 ha UAA, which amounts to $5.6 \%$ of the total UAA (GFR 2006). 
irreversibility effect of ex-ante regulations and ex-post liability rules increase the costs of minimum distance policies and hence increase the minimum farm size for adoption.

This has implications for empirical studies. Investigations assessing the potential adoption of GM crops need to consider the ex-ante regulations as well as ex-post liability regimes. Further, ex-ante regulations and ex-post liability regimes need to be differentiated between reversible and irreversible benefits and costs as they have a different effect on adoption. The model we have presented allows a ranking of different liability regimes as discussed in section 5.2 with respect to the implications on adoption. While the ranking is not surprising we provide a rationale, which so far has been missing (Koch 2008).

The minimum distance requirements that many countries consider for or have already included in their coexistence policy discriminates against smaller farms. This has implications for the distribution of adopting farms. Areas with on average smaller farm sizes will experience lower rates of adoption and a reduction in their competitiveness. This discriminatory aspect of an ex-ante regulation has so-far not been considered within the literature on the effects of ex-ante regulations versus ex-post liability rules. A possible corner solution for those areas is either all farmers adopt the technology or none, and in the latter case, becoming a GM-free zone.

The regulatory choice has also implications for the comparative advantage of farms as opportunity costs change. In Europe, where in many cases potential GM farmers face ex-ante regulations and ex-post liability rules increase the costs of adoption the comparative advantage of the GM farmer will be reduced. This has implications for the long run. In cases where comparative advantage is with the GM farmer, the GM GM farmer may out-compete the non-GM farmer. Coexistence policies can change the outcome. The welfare losses of such kind of policies are often not considered by decision makers but can be substantial (Wesseler 2009) and deserves further attention.

The example of Brandenburg demonstrates that low adoption of an otherwise economical technology is a relevant issue and can be explained by using our model. The question to what extent ex-ante regulation and ex-post liability and the irreversibility effect do prevent the adoption of GM crops in Europe is an empirical one. We have provided with our analysis a theoretical framework that 
can be used for such an empirical study. As Smyth and Kershen (2006) have pointed out such kind of model may not be limited to the case of GM crops only.

Further, our results suggest a combination of ex-ante regulations and ex-post liability rules is superior over ex-ante regulations as precautionary measures only, except for the trivial case where ex-ante regulations are supposed to stop GM planting at all. This can be explained by the fact that ex-ante regulations of GM crop planting can not prevent harm by 100 per cent. On would expect farmers to endogeneize minimum distances given liability rules resulting in the demand for flexible ex-ante regulations as has been debated by Demont et al. (2009) and Desquilbert and Bullock (2009). Our model illustrates that ex-post liability rules for the GM farmer provides incentives for ex-ante distance keeping to non-GM farms to reduce ex-post liability costs. ${ }^{7}$ This point in more general has been discussed recently in detail by Shleifer (2010). Our model results support his argument despite having ex-post liability rules ex ante measures do emerge to reduce ex-post liability costs.

7 Reinforcing voluntary ex-ante measures might be hold-up problems arising if an agreement between neighbours has been made but not kept. If the GM farmer is liable he may want to reduce additional hold-up costs even so he may win his case at court as a contract has been breached. A similar reasoning applies of course for the non-GM farmer. 
conomics: The Open-Access, Open-Assessment E-Journal

\section{References}

Beckmann, V. (2005) Comment on Soregaroli and Wesseler: Minimum distance requirements and liability: implications for co-existence. In J. Wesseler (Ed.), Environmental Costs and Benefits of Transgenic Crops. Dordrecht: Springer.

Beckmann, V., and J. Wesseler (2007). Spatial Dimension of Externalities and the Coase Theorem: Implications for Co-existence of Transgenic Crops. In W. Heijman (Ed.), Regional Externalities. Dordrecht: Springer.

Beckmann, V., C. Soregaroli, and J. Wesseler (2006). Co-Existence Rules and Regulations in the European Union. American Journal of Agricultural Economics 88: 1193-1199.

Boyer, M., and D. Porrini (2004). Modelling the choice between regulations and liability in terms of social welfare. Canadian Journal of Economics 37: 590612.

Breustedt, G., J. Müller-Scheeßel, and U. Latacz-Lohmann (2008). Forecasting the Adoption of GM Oilseed Rape: Evidence from a Discrete Choice Experiment in Germany. Journal of Agricultural Economics 59(2):237-256.

Bundesrat. (2005). Gesetz zur Neuordnung des Gentechnikrechts. Bundesgesetzblatt 2005: Teil I Nr. 8, February 3, 2005.

Calcott, P. and S. Hutton (2006). The choice of a liability regime when there is a regulatory gatekeeper. Journal of Environmental Management and Economics 51, 153-164.

Commission of the European Communities (2006). Annex to the Communication from the Commission to the Council and the European Parliament. Report on the implementation of national measures on the coexistence of genetically modified crops with conventional and organic farming. COM (2006) 104. Brussels.

Commission of the European Communities (2005). Questions and Answers on the Regulation of GMOs in the European Union. Available at http://europa.eu.int/comm/food/food/biotechnology/gmfood/qanda_en.htm. Update: 24-10-2005. 
Commission of the European Communities (2003). Commission Recommendation of 23 July 2003 on guidelines for the development of national strategies and best practices to ensure the coexistence of genetically modified crops with conventional and organic farming. Official Journal of the European Communities L189/36-47, 29.7.2003.

Commission of the European Communities (2000). Commission Regulation (EC) No 49/2000 of 10 January 2000 amending Council Regulation (EC) No 1139/98 concerning the compulsory indication on the labelling of certain foodstuffs produced from genetically modified organisms of particulars other than those provided for in Directive 79/112/EEC. Official Journal of the European Communities L6/13-14, 11.1.2000.

Conner, D. S. (2003). Pesticides and Genetic Drift: Alternative Property Rights Scenarios. Choices (First Quarter), 5-7.

Degenhardt, H., F. Horstmann, and N. Mülleder (2003). Bt-Mais in Deutschland. Erfahrungen mit dem Praxisanbau von 1998-2002. Sonderdruck aus MAIS 2/2003, pp. 1-4.

Demont, M., K. Dillen, W. Daems, C. Sausse, E. Tollens, and E. Mathijs (2009). On the proportionality of EU spatial ex ante coexistence regulations. Food Policy 34(6):508-518.

Demont, M., J. Wesseler, and E. Tollens (2004). Biodiversity versus transgenic sugar beet: the one Euro question. European Review of Agricultural Economics 31, 1-18.

Desquilbert, M. and D. S. Bullock (2010). On the proportionality of EU spatial ex ante coexistence regulations: A comment. Food Policy (forthcoming).

Dixit, A. K. and R. S. Pindyck (1994). Investment under Uncertainty. Princeton: Princeton University Press.

Ewerhart, C. and P. W. Schmitz (1998). Ex Post Liability for Harm vs. Ex Ante Safety Regulation: Substitutes or Complements? Comment. American Economic Review, 88:1027.

Falck Zepeda, J. (2006). Coexistence, Genetically Modified Biotechnologies and Biosafety: Implications for Developing Countries. American Journal of Agricultural Economics 88: 1200-1208. 
GFR (Gentechnikfreie Regionen) (2006). Übersicht: Gentechnikfreie Regionen in Deutschland (Stand 08.12.2006) http:/www.gentechnikfreie-regionen.de/ fileadmin/content/download_allg/gesamtuebersicht_dez06.pdf.

Kershen, D. L. (2002). Legal Liability Issues in Agricultural Biotechnology. National AgLaw Center Publications. University of Arkansas, School of Law.

Koch, B. (Ed.) (2008). Economic Loss Caused by Genetically Modified Organisms. Springer Verlag: Wien.

Kolstad, C. D., T. S. Ulen, and G. V. Johnson (1990). Ex Post Liability for Harm vs. Ex Ante Safety Regulation: Substitutes or Compliments. American Economic Review 80, 888-901.

Landtag Brandenburg (2005). Antwort der Landesregierung auf die kleine Anfrage Nr. 884: Maiszünsler und der Anbau gentechnisch veränderten Mais. Drucksache 4/2309. Potsdam.

Larson, B. A. (1996). Environmental Policy Based on Strict Liability: Implications of Uncertainty and Bankruptcy. Land Economics 72:33-42.

Larson, B. A., and M. K. Knudson (1991). Public Regulation of Agricultural Biotechnology Field Tests: Economic Implications of Alternative Approaches. American Journal of Agricultural Economics 73:1074-1082.

Morel, B., S. Farrow, F. Wu, and E. A. Casman (2003). Pesticide resistance, the precautionary principle, and the regulation of Bt Corn: real option and rational option approaches to decision-making. In R. Laxminarayan (Ed.), Battling Resistance to Antibiotics and Pesticides. Washington DC: Resources for the Future.

Nischwitz, G., C. Kuhlicke, T. Bodenschatz, B. Thießen, and K. Tittel (2004). Sondierungsstudie gentechnikfreie Regionen in Deutschland. Eine sozioökonomische Analyse am Beispiel der brandenburgischen Uckermark. Institut für ökologische Wirtschaftforschung, Büro Hannover.

Roe, B. (2004). Optimal sharing of foodborne illness prevention between consumers and industry: the effect of regulation and liability. American Journal of Agricultural Economics 86: 359-374. 
Scatasta, S., J. Wesseler, and M. Demont (2006). Irreversibility, Uncertainty, and the Adoption of Transgenic Crops: Experiences from Applications to HT sugar beet, HT corn, and Bt Corn. In J. Alston, R. Just, and D. Zilberman (Eds.), Economics of Regulation of Agricultural Biotechnology. Berlin: Springer.

Schmitz, P. (2000). On the joint use of liability and safety regulation. International Review of Law and Economics 20: 371-382.

Shavell, S. (1987). Economic Analysis of Accident Law. Cambridge: Harvard University Press.

Shleifer, A. (2010). Efficient Regulation. NBER Working Paper No. 15651. Cambridge, MA: National Bureau of Economic Research.

Smyth, S. and D. Kershen. (2006). Agricultural Biotechnology: Legal Liability Regimes from Comparative and International Perspectives. Global Jurist Advances 6, Article 3.

Smyth, S., G. G. Khachatourians, and P. W. B. Phillips (2002). Liabilities and Economics of Transgenetic Crops. Nature Biotechnology 20: 537-541.

Soregaroli, C. and J. Wesseler (2005). Minimum distance requirements and liability: implications for co-existence. In J. Wesseler (Ed.), Environmental Costs and Benefits of Transgenic Crops. Dordrecht: Springer.

Standortregister (2006). Bundesamt für Verbraucherschutz und Lebensmittelsicherheit. http://194.95.226.237/stareg_web/bundeslandStatistic.do

Statistische Berichte (2006a). C IV 7 - 2j/05: Größenstruktur der Landwirtschaftlichen Betriebe im Land Brandenburg 2005. Potsdam: Landesbetrieb für Datenverarbeitung und Statistik.

Statistische Berichte (2006b). C $11-\mathrm{j} / 05$ : Bodennutzung der landwirtschaftlichen Betriebe im Land Brandenburg 2005. Potsdam: Landesbetrieb für Datenverarbeitung und Statistik.

Statistische Berichte (2006c). C IV 2 - 2j/05: Betrieb mit ökologischem Landbau im Land Brandenburg 2005. Potsdam: Landesbetrieb für Datenverarbeitung und Statistik.

Viscusi, W. K., and M. J. Moore (1993). Product Liability, Research and Development, and Innovation. Journal of Political Economy 101: 161-184. 
Weaver, R. D. and J. Wesseler (2004). Monopolistic pricing power for transgenic crops when technology adopters face irreversible benefits and costs. Applied Economics Letters 15: 969-973.

Wesseler, J. (2009). The Santaniello Theorem of Irreversible Benefits. AgBioForum 12(1): 8-13.

Wesseler, J. (2003). Resistance Economics of Transgenic Crops. A Real Option Approach. In R. Laxminarayan (Ed.), Battling Resistance to Antibiotics and Pesticides. Washington DC: Resources for the Future.

Wesseler, J., S. Scatasta, and E. Nillesen (2007). The Maximum Incremental Social Tolerable Irreversible Costs (MISTICs) and other Benefits and Costs of Introducing Transgenic Maize in the EU-15. Pedobiologia 51(3):261-269.

Zaid, A, H. G. Hughes, E. Porceddu, and F. Nicholas (2001). Glossary of Biotechnology for Food and Agriculture. Rome: FAO. 


\section{Economics: The Open-Access, Open-Assessment E-Journal}

\section{Appendix}

Proof of $\partial \kappa_{i}^{\ell} / \partial \gamma_{i}>0$.

To improve the readability of the equations the following notation will be used:

$$
\begin{aligned}
& \kappa_{i}^{\ell}=\left(\frac{\beta_{1_{i}}}{\beta_{1_{i}}-1}\right)\left(\rho_{i}-\alpha_{i}+\gamma_{i}\right) I R_{i}^{\ell} \\
& \beta_{1_{i}}=\frac{1}{2}-\frac{\alpha_{i}}{\sigma_{i}^{2}}+\sqrt{\left(\frac{\alpha_{i}}{\sigma_{i}^{2}}-\frac{1}{2}\right)^{2}+\frac{2\left(\rho+\gamma_{i}\right)}{\sigma_{i}^{2}}>1} \\
& v_{i}=\sqrt{\left[\frac{\alpha_{i}}{\sigma_{i}^{2}}-\frac{1}{2}\right]^{2}+\frac{2\left(\rho_{i}+\gamma_{i}\right)}{\sigma_{i}^{2}}}=\sqrt{\chi_{i}^{2}+q_{i}} \\
& \chi_{i}=\left[\frac{\alpha_{i}}{\sigma_{i}^{2}}-\frac{1}{2}\right] \\
& q_{i}=\frac{2\left(\rho_{i}+\gamma_{i}\right)}{\sigma_{i}^{2}}>0 .
\end{aligned}
$$

Note: $\alpha_{i}$ is the drift rate, $\sigma_{i}^{2}$ the variance of a geometric Brownian motion, $\rho_{i}$ the discount rate and $\gamma_{i}$ the mean arrival rate of a Poisson process. $i$ indicates the $i$-th farm. 
Economics: The Open-Access, Open-Assessment E-Journal

Proof:

$$
\begin{aligned}
& \partial \kappa_{i}^{\ell} / \partial \gamma_{i}>0 \\
& \Rightarrow\left(\frac{\beta_{1_{i}}}{\beta_{1_{i}}-1}\right)>\frac{\partial \beta_{1_{i}}}{\partial \gamma_{i}}\left(\rho_{i}-\alpha_{i}+\gamma_{i}\right) ; \quad \frac{\partial \beta_{1_{i}}}{\partial \gamma_{i}}=\frac{1}{\sigma_{i}^{2} v_{i}}
\end{aligned}
$$

Substituting $\frac{\partial \beta_{1_{i}}}{\partial \gamma_{i}}=\frac{1}{\sigma_{i}^{2} v_{i}}$ provides

$$
\left(\frac{\beta_{1_{i}}}{\beta_{1_{i}}-1}\right)>\frac{\left(\rho_{i}-\alpha_{i}+\gamma_{i}\right)}{\sigma_{i}^{2} v_{i}}
$$

Assuming $\alpha_{i} \geq 0$ the term $\frac{\alpha_{i}}{\sigma_{i}^{2} v_{i}}$ can be ignored and we get

$$
\begin{aligned}
& \left(\frac{\beta_{1_{i}}}{\beta_{1_{i}}-1}\right)>\frac{\left(\rho_{i}-\alpha_{i}+\gamma_{i}\right)}{\sigma_{i}^{2} v_{i}} \\
& \Rightarrow\left(\frac{\beta_{1_{i}}}{\beta_{1_{i}}-1}\right)>\frac{\left(\rho_{i}+\gamma_{i}\right)}{\sigma_{i}^{2} v_{i}} \\
& \Rightarrow\left(\frac{\beta_{1_{i}}}{\beta_{1_{i}}-1}\right)>\frac{q_{i}}{v_{i}} \\
& \Rightarrow \beta_{1_{i}} \frac{v_{i}}{q_{i}}>\left(\beta_{1_{i}}-1\right)
\end{aligned}
$$




\section{Economics: The Open-Access, Open-Assessment E-Journal}

Equation [A2] will be true, if $\frac{v_{i}}{q_{i}}>1$. As $v_{i}>\chi_{i}+1$ and $q_{i}>\chi_{i}+0.5$ it follows

$$
\begin{aligned}
& \frac{v_{i}}{q_{i}}>1 \\
& \Rightarrow v_{i}>q_{i} \\
& \Rightarrow v_{i}^{2}>q_{i}^{2} \\
& \Rightarrow \chi_{i}^{2}+\chi_{i}+0.5>\chi_{i}^{2}+\chi_{i}+0.25
\end{aligned}
$$




\section{Conomics}

The Open-Access, Open-Assessment E-Journal

\section{Please note:}

You are most sincerely encouraged to participate in the open assessment of this article. You can do so by either recommending the article or by posting your comments.

Please go to:

www.economics-ejournal.org/economics/journalarticles/2010-9

The Editor 